IZA DP No. 7709

Household Consumption at Retirement:

A Regression Discontinuity Study on French Data

Nicolas Moreau

Elena Stancanelli

October 2013 


\title{
Household Consumption at Retirement: A Regression Discontinuity Study on French Data
}

\author{
Nicolas Moreau \\ University of Reunion Island \\ Elena Stancanelli \\ CNRS, Centre d'Economie de la Sorbonne, \\ Université Paris 1, Paris School of Economics and IZA
}

\section{Discussion Paper No. 7709 \\ October 2013}

\author{
IZA \\ P.O. Box 7240 \\ 53072 Bonn \\ Germany \\ Phone: +49-228-3894-0 \\ Fax: +49-228-3894-180 \\ E-mail: iza@iza.org
}

\begin{abstract}
Any opinions expressed here are those of the author(s) and not those of IZA. Research published in this series may include views on policy, but the institute itself takes no institutional policy positions. The IZA research network is committed to the IZA Guiding Principles of Research Integrity.

The Institute for the Study of Labor (IZA) in Bonn is a local and virtual international research center and a place of communication between science, politics and business. IZA is an independent nonprofit organization supported by Deutsche Post Foundation. The center is associated with the University of Bonn and offers a stimulating research environment through its international network, workshops and conferences, data service, project support, research visits and doctoral program. IZA engages in (i) original and internationally competitive research in all fields of labor economics, (ii) development of policy concepts, and (iii) dissemination of research results and concepts to the interested public.
\end{abstract}

IZA Discussion Papers often represent preliminary work and are circulated to encourage discussion. Citation of such a paper should account for its provisional character. A revised version may be available directly from the author. 


\title{
ABSTRACT \\ Household Consumption at Retirement: A Regression Discontinuity Study on French Data
}

\begin{abstract}
Earlier literature has investigated the drop in household consumption upon retirement of the head of the household, the so-called "retirement consumption puzzle". Here, we expand on these studies by considering also retirement of the wife, thus distinguishing households in which the wife is a "housewife" from 'dual-earners'. We use a regression discontinuity approach to estimate the effect of each partner's retirement on household consumption. We use for the analysis data drawn from the French Consumer Budget Survey 2001 that collected two-week expenditure diaries. We find a significant and sizable drop in food and clothes expenditure upon retirement of the male partner. However, the drop in food expenditure is not robust to specification checks and it becomes statistically insignificant when dropping from the sample couples in which the wife is a housewife.
\end{abstract}

JEL Classification: D12, J22, J14, C1

Keywords: consumption, ageing, retirement, regression discontinuity

Corresponding author:

Elena Stancanelli

CNRS, Sorbonne Economics Research Center (CES)

Maison des Sciences Economiques

106-112 Boulevard de l'Hopital

75013 Paris

France

E-mail: elena.stancanelli@univ-paris1.fr 


\section{Introduction}

Retirement is an important field of research in economics. Dramatic changes in household consumption upon retirement of the head of the household have been documented in the literature. However, older individuals live in a couple and many women nowadays are active in the labor market. Therefore, it is relevant to study also the effect of female retirement on household consumption. Here we exploit the law on retirement age in France to identify the effect of each partner's retirement on household consumption using a regression discontinuity approach.

Earlier studies concluded that consumption drops dramatically at retirement (for example, Hamermesh, 1984) and that this is partly explained by increased home production and reduction in work-related expenditure (Aguiar and Hurst, 2005 and 2007; Hurd and Rohwedder, 2007 and 2008; Hurst, 2008), and possibly, children leaving home (Battistin et al., 2009). In particular, Battistin et al. (2009) use a regression discontinuity model to conclude that the reduction in household non-durable consumption at retirement is partly explained by adult children leaving the parental household. Lundberg et al. (2003), using data drawn from the Health and Retirement Survey, find an insignificant drop in consumption at retirement for singles. The authors explain its significance for married men by arguing that women expect to live longer and thus they act as to reduce current consumption when the husband retires -and succeed to do so because retirement of the husband lowers his bargaining power. These authors did not allow for retirement of the wife or distinguish dualearners out of the larger couple population.

Moreover, this is the first study that investigates the effects of retirement on household consumption for France. Most of the literature on the relation between (male) retirement and consumption relates to the United States (see, for instance, Hamermesh, 1984; Aguiar and Hurst, 2013; Fisher et al., 2008; Lundberg et al., 2003) or the United Kingdom (see for example, Banks et al., 1998) or Italy (Battistin et al., 2009; Miniaci et al., 2010). It seems relevant to study the effect of retirement on household consumption in France, which is characterized by different earnings profiles and retirement institutions than the UK, the USA or Italy. 
Therefore, we investigate the effect of each partner's retirement on household consumption using data drawn from the French Consumer Budget Survey 2001 that collected two-week expenditure diaries. We exploit the legal retirement age in France to identify the effect of individual retirement on non-durable consumption expenditure. We find evidence that the individual retirement probability increases significantly upon reaching legal retirement age, which supports our modelling approach. We conclude that food expenditure drops significantly upon retirement of the 'husband" though this effect becomes statistically insignificant when dropping couples with a 'housewife' from the sample. This suggests that employment of the 'wife' sheds the household food consumption from falling upon husband's retirement, a fact that has gone unobserved in earlier studies.

Moreover, we find that clothing consumption drops dramatically when the husband retires and this effect is robust to alternative sample cuts and several specification checks. Remarkably though food or clothing consumption do not fall upon wife's retirement, perhaps due to the fact that she is often the second earner in the household. Finally, we conclude that the size of the reduction in household food and clothing consumption upon husband's retirement is much larger than that documented in earlier studies for other countries, which might be explained by the earnings distribution being much more compressed in France than in other OECD countries.

This paper is structured as follows. Section 2 describes the data and the sample selection. Section 3 presents the empirical model. Exploratory graphical analysis follows in Section 4. Section 5 discusses the results of estimation and Section 6 concludes the paper.

\section{The data}

The data for the analysis are drawn from the French Consumer Budget Survey ("Enquête Budget des Familles") 2001 that collected two-week expenditure diaries in addition to a household and an individual questionnaire (see also Olivier Donni and Nicolas Moreau, 2007 for a discussion of these data and an application to household economics). Three personal interviews were carried out at the respondents' house to collect household and individual information in addition to the main expenses items. Moreover, all individuals aged above 14

\footnotetext{
${ }^{1}$ For simplicity, we shall denote throughout the paper as the "husband", the man in the couple, and as the "wife", the woman in the couple, even if we include in our sample also unmarried couples (see Section 2 for an account of data selection steps).
} 
years in the household were asked to fill in a 14-days expenses diary, reporting in writing their expenses or joining the shop receipts. The overall response rate was high: 62 per cent of all households contacted answered the expenses diary as well as the household and individual questionnaires.

\section{Sample selection}

First, we selected couples using the following criteria:

1. They were either cohabiting or married couples;

2. And with both partners aged between 50 and 70 years.

The first criterion is applied to avoid sample selection bias (as dual-earners may cohabit more often than other couples. ${ }^{2}$ Besides, due to the small number of cohabiting couples at older age it is not possible to analyze the two groups separately. The second criterion sets bounds of ten years on each side of age 60, which is by law the earliest retirement age for most workers in France. In particular, because some individuals may retire earlier (due to special early retirement schemes) or later (due to delayed entry into the labour market), we use a fuzzy regression discontinuity design -this allows for a discrete increase in the probability of retirement at age 60 (see Section 3).

Next, we drew two different samples of couples for the analysis on the basis of the activity status of each partner as follows.

- The first sample (hereafter Sample A) includes couples in which the husband is either employed or retired and the wife may report any economic activity (employed, retired, other inactive). This gives a sample of 1567 observations.

- The second sample (Sample B) includes couples in which each partner is either employed or retired from work. This produced a sample of 1067 couple that can be used to estimate the effect of both partners' retirement on household consumption.

The first of the two samples (sample A) is similar to the sample of couples used for example, in Lundberg et al. (2003) that did not allow for retirement of the wife. In contrast, sample B includes only partners that report their main employment status to be either employed or

\footnotetext{
${ }^{2}$ For example, Bloemen and Stancanelli (2013), using a sample of couples drawn from the French Labor Force Surveys find that cohabitation is positively associated with dual-earnship.
} 
retiree and thus, we can use it to estimate the effect of husband's and wife's retirement on household consumption.

\section{Retirement Status, Employment and Age}

Retirement status is defined on the basis of individual subjective answer to a standard question on the main economic activity at the time of the survey. Employment is defined similarly, using the same question. The survey collected information on the month and year of birth, which combined with information on the date the survey was collected, enable us to construct approximately continuous measure of partners' age at the time of the survey. This is important since age is our running variable in the regression discontinuity model (see Section $3)$.

\section{Consumption}

The survey collected detailed diary expenditure data on two-week food consumption and also other non-durable and durable consumption on a larger time scale. The two-weeks Euro amounts of expenditure were transformed by the survey collectors into yearly Euro amounts. We study here changes in household consumption at retirement distinguishing total nondurable household expenditure from food expenditure (excluding alcohol and tobacco) and clothing expenditure (including adults' and children's clothes and shoes). These were the items analyzed in most earlier studies.

\section{Descriptive statistics}

Descriptive sample statistics are provided in Table 1. The proportion of retired men is about 59 per cent in sample A (see Section 2 above for details of sample selection) and 58 per cent in sample B (dropping couples in which the wife is say a "housewife"). In contrast, only 31 per cent of the women in the couples of sample A have retired from work against 45 per cent in sample B. This is reasonable since first of all, the wife is on average two years younger than the husband -in our sample the average age of women is 58 against 60 for men- and also sample A includes couples in which the wife is a housewife and thus, a smaller of proportion of older women in this sample are "retirees". The other individual and household characteristics do not vary substantially across the two samples (sample A or sample B). Over 93 per cent of the partners are French nationals. As far as education goes ${ }^{3}$, primary school is

\footnotetext{
${ }^{3}$ We use information on the highest completed education level to construct a series of education dummies.
} 
the reference category and many of the older partners in our sample are in the reference group -as this was the compulsory education level at the time these people were at school, in France. About 95 per cent of the couples are married. The number of adult children having left home is about two. Only in few of the households in our sample there are adult children still living at home -the average number of adult children at home is 0.32 . Over 15 per cent of the sample resides in the region of Paris ("Ile de France"). Average household expenditure is slightly smaller in sample A -which includes couples with a housewife- than in sample B. This is in line with findings by Bloemen and Stancanelli (2013) who find that men in male breadwinner households earn on average less than men in dual-earner households in France about the same period of time. In particular, average non-durable consumption is equal to about 20400 Euro per year, in current euro, for couples in which partners are either employed or retired (Sample B) and 19286 Euro per year in the larger sample which includes also couples with a housewife (Sample A). Food expenditure represents on average about a quarter of total household non-durable expenditure while clothing accounts for about 7 per cent of total household non-durable consumption, on average.

\section{The empirical model}

Because the individual decision to retire from work may not be independently determined from the individual consumption choices -for example, individuals that expect large drops in income at retirement may tend to retire later than other- we exploit the legislation in France that sets 60 as the earliest retirement age for most workers to instrument the effect of retirement in our consumption model. The existence of a legal retirement age creates a discontinuity in the probability of retirement (as a function of age) that enables us to apply a regression discontinuity approach. Excellent literature reviews of regression discontinuity methods are provided, for example, by David Lee and Thomas Lemieux (2010), Wilbert van der Klaauw (2008), or Guido Imbens and Thomas Lemieux (2007). The main advantage of regression discontinuity over other competing approaches is that it is closer to a natural experimental design as individual close to the discontinuity are likely to be very similar in many respects and thus we can neatly identify the effect of retirement (instrumented with the age discontinuity) on consumption. An application of regression discontinuity to the retirement decision of the head of the household is given in Battistin et al. (2009) who investigate the effect of retirement of the head of the household on household consumption. 
Recently, Stancanelli and van Soest (2012) use a similar approach to estimate the effect of partners' retirement on time allocation and notably, house work.

Under this set up, identification of the effect of retirement on consumption (the outcome variable) is achieved thanks to the sudden and large increase in retirement (the treatment) at the point of discontinuity (age 60) in the running variable (age). Individuals cannot manipulate their age -and this is one of the requirements for using a regression discontinuity approach (see, for example, Lee and Lemieux, 2010). In our data, year and month of birth were collected, and we also know the day, month and year of the survey interview. Therefore, we assume that age is measured continuously. There are no other policy measures that affect individuals reaching age 60 in France. Retirement is also measured at the time of the interview.

However, we need to account for the fact that some people may retire earlier than sixty -due to special early retirement schemes or specific employment sector rules - and others later, though in France, unemployment, maternity and sick leave periods are fully covered by pension rights, so that interrupted labour market experience will not translate into smaller pension benefits or into a longer working life. ${ }^{4}$ We use a so-called Fuzzy Regression Discontinuity design - the jump in the probability of retirement at age 60 (or 720 months) is greater than zero but less than one.

Let $\mathrm{R}_{i j}$ be a dummy for retirement equal to one if partner $j(j=f, m)$ in household $i$ has retired from market work and zero otherwise. Let $\mathrm{D}_{i j}$ be a dummy that takes value one when individuals have reached age 60 and zero otherwise, and let $\mathrm{C}_{i}$ be household consumption. The fuzzy regression discontinuity design can be estimated by specifying a two stages least square model of the effect of retirement -instrumented with a dummy for being aged at least 60 (720 months or more) and full interactions of this dummy with an individual age polynomial- on household consumption (see, for example, van der Klaauw (2008). We also adjust the standard errors of the model as recommended in the RD literature.

1) $C=\alpha^{c j}+R_{j} \beta^{c j}+f\left(A_{j} e_{j}-720\right) \gamma^{c j}+Z_{j} \beta^{c j}+v_{j}^{c}$

2) $R_{j}=\alpha^{r j}+D_{j} \gamma^{r j}+D_{j} f(A g e j-720) \delta^{r j}+f\left(A_{g e}-720\right) \gamma^{r j}+Z_{j} \beta^{r j}+v_{j}^{r}$.

\footnotetext{
${ }^{4}$ See, for example, Blanchet and Pele (1997) for more details of the French pension system. In 2010, the legal early retirement age was set at 62 years, but this will become effective only in 2018. Hairault, Langot and Sopraseuth (2010) model the employment effect of the distance to the legal retirement age in France in a theoretical job search framework and conclude that increasing the legal retirement age is likely to increase employment rates of older workers. See also Duguet and Simmonet (2007) and Sédillot and Walraet (2002).
} 
Equation 1 is the outcome equation and equation 2 is the first stage equation for retirement in our 2SLS Fuzzy Regression Discontinuity model (the subscript i for the household has been suppressed for simplicity and $\mathrm{j}=\mathrm{m}$ here). The functions $\mathrm{f}$ is a flexible polynomial in age which is specified here as a quadratic: $\mathrm{f}\left(\mathrm{Age}_{\mathrm{j}}-720\right)=\left(\mathrm{Age}_{\mathrm{j}}-720\right)+\left(\mathrm{Age}_{\mathrm{j}}-720\right)^{2}$. The threshold 720 months corresponds to the minimum legal retirement age for most workers in France. We assume that the covariates other than age (denoted by $\mathrm{Z}$ here) are not discontinuous at age 60 (and we also test for this in the next Section 4).The vector $\mathrm{Z}$ contains other individual and household characteristics such as education dummies, marital status, French nationality, number of children still leaving at home, number of children having left home, and area of residence.

Next, we study the effect of the husband and the wife's retirement on household consumption. The regression discontinuity model is now specified as two stages least square model in which we allow for two first stage regressions, to instrument the effect of the wife's and the husband's retirement on household consumption, respectively. Again we also correct the standard errors.

3) $\mathrm{C}=\alpha^{\mathrm{c}}+\mathrm{R}_{f} \beta^{\mathrm{cf}}+\mathrm{R}_{m} \beta^{\mathrm{cm}}+\mathrm{f}\left(\mathrm{Age}_{f}-720\right) \gamma^{\mathrm{cf}}+\mathrm{f}\left(\mathrm{Age}_{m}-720\right) \gamma^{\mathrm{cm}}+\mathrm{Z}_{m} \beta^{\mathrm{cm}}+\mathrm{Z}_{f} \beta^{\mathrm{cf}}+v^{\mathrm{c}}$

4) $\mathrm{R}_{f}=\alpha^{\mathrm{f}}+\mathrm{D}_{f} \gamma^{\mathrm{rff}}+\mathrm{D}_{m} \eta^{\mathrm{rmf}}+\mathrm{D}_{f} \mathrm{f}\left(\mathrm{Age}_{f^{-}} 720\right) \delta^{\mathrm{rff}}+\mathrm{D}_{m} \mathrm{f}\left(\mathrm{Age}_{m^{-}} 720\right) \delta^{\mathrm{rmf}+} \mathrm{f}\left(\mathrm{Age}_{f^{-}} 720\right) \gamma^{\mathrm{rff}}+\mathrm{f}\left(\right.$ Age $_{m^{-}}$ 720) $\gamma^{\mathrm{rmf}}+\mathrm{Z}_{m} \beta \mathrm{r}^{\mathrm{mf}}+\mathrm{Z}_{f} \beta^{\mathrm{rff}}+v^{\mathrm{f}}$

5) $\mathrm{R}_{m}=\alpha^{\mathrm{m}}+\mathrm{D}_{f} \gamma^{\mathrm{rfm}}+\mathrm{D}_{m} \eta^{\mathrm{rmm}}+\mathrm{D}_{f} \mathrm{f}\left(\operatorname{Age}_{f}-720\right) \delta^{\mathrm{rfm}}+\mathrm{D}_{m} \mathrm{f}\left(\operatorname{Age}_{m^{-}} 720\right) \delta^{\mathrm{rmm}+} \mathrm{f}\left(\operatorname{Age}_{f^{-}} 720\right) \gamma^{\mathrm{rfm}}+$ $\mathrm{f}\left(\mathrm{Age}_{m^{-}}-720\right) \gamma^{\mathrm{rmm}}+\mathrm{Z}_{m} \beta \mathrm{r}^{\mathrm{mm}}+\mathrm{Z}_{f} \beta^{\mathrm{rfm}}+v^{\mathrm{m}}$.

We estimate these models for total nondurable consumption and for two sub-categories of nondurable consumption: food and clothing (clothes and shoes) expenditure. For clothing consumption, $11.9 \%$ of sample A (see Section 2) and $10.6 \%$ of sample B (see section 2) report no clothing consumption on the two-week diary. ${ }^{5}$ It seems reasonable to assume that most of these zero expenditure may capture "infrequencies" (the fact that new clothes and shoes are not bought every day) rather than "censoring" (some kind of selection process underlying who buys new clothes and shoes), and thus, we use a linear specification also for clothing consumption (see, for example, Jay Stewart, 2009, for a discussion).

\footnotetext{
${ }^{5} \mathrm{We}$ do not observe any zero in non-durable expenditure while few observations (less than five in total) that reported no food consumption were dropped from the sample.
} 


\section{Exploratory graphical analysis}

We first run some exploratory graphical analysis. ${ }^{6}$ Charts 1 illustrate the age distribution of partners. ${ }^{7}$ Charts 2 shows the raw distribution of retirement probabilities by age using bins of size ten months for partnered women and men, as standard in the regression discontinuity approach -remember age is measured in months and 720 months corresponds to age 60 which is our cut-off point as this is the legal minimum retirement age for most workers in France. There are large jumps at age 60 (720 months of age) in the retirement probabilities of both the husband and the wife, which support our identification strategy.

Next, we plot the consumption outcomes against each partner's age in Charts3, which depict, respectively, total expenditure, food expenditure and clothing expenses as a function of each partner's age. There are detectable drops in total, food and clothing expenditure when the husband reaches legal retirement age, while the patterns are less clear-cut for the wife. Chart 4 shows the predicted retirement probability as a function of covariates other than age, to check for breaks in retirement patterns possibly due to other covariates also varying at age 60 .We first predict retirement probabilities as a function of covariates other than age and then plot the predicted probabilities against age. By comparing Charts 2 to Charts 4, it is clear that covariates other than age do not jump up at age 60 (720 months) for either partner. The covariates considered here are the same as those included in the parametric models later on: partners' education and nationality dummies, area of residence, marital status, number of children that left the household and number of children still living at home. ${ }^{8}$

Finally, Charts 4 and 5 produce similar graphical evidence as in Charts 2 and 3, respectively, using age polynomials from the left and the right of the discontinuity to predict retirement and household expenditures, as usual in RD analysis. The jumps in retirement probabilities of either partner at age 60 (720 months of age) are very large (Charts 5). Total household

\footnotetext{
${ }^{6}$ To save space, only the exploratory graphical analysis performed on Sample B is reported. Sample A exhibits similar patterns.

${ }^{7}$ Following the approach suggested by McCrary (2008) to check for possible breaks in the sample age distribution, we computed a McCrary test statistic which is equal, respectively, to 0.130 with a standard error of 0.182 for partnered men and to 0.559 with a standard error of 0.222 for partnered women. Thus, there is a statistically significant break at age 60 in the age distribution of partnered women in the sample while there is no significant discontinuity for men. This finding does not appear to be related to manipulation of the running variable (age) by women or to women above 60 dropping out of the sample, as their husband does not drop out.

${ }^{8}$ We distinguish these two categories of children since Battistin et al. (2009) show that children leaving home explain most of the drop in household consumption at retirement of the household head.
} 
consumption and household food expenditure appear to drop when the man in the couple turns 60 but there are no sharp drops in consumption when the female partner turns 60 (see Charts 6). Similar patterns are observed for clothing expenditure (see Charts 7) which shows a drop when the male partner is of age 60 and above but does not fall substantially upon her reaching age 60 and above.

\section{Results of estimation}

We have estimated Regression Discontinuity models of the effect of partners' retirement (instrumented exploiting the legal retirement age discontinuity) on household total nondurable consumption, food and clothing expenditure (see Section 3 for details of the model). The covariates included (or excluded) from the models are education dummies, French nationality, marital status and area of residence dummies, number of children still living at home and number of adult children that left home. The model was first estimated controlling only for retirement of the husband (on couples of sample A, see Section 2 for some discussion), and next controlling for retirement of both the husband and the wife (on couples of sample B, see Section 2).

Results of estimation of the first stage instrumental variable regressions for the model (see Section 3) are given in Table 2. We estimated linear probability models of retirement of the husband (model 1) and retirement of either the husband or the wife (model 2). Robustness checks narrowing the sample age boundaries on the two sides of the age discontinuity selecting couples in which both partners are aged 52 to 68 years- and dropping covariates from the model are given in Table 3. Table 4 provides then the 2SLS estimates of the effect of retirement (instrumented using the first stage regressions in Table 2), on total household consumption. Table 5 displays the results for the outcome of food consumption and Table 6 for clothing expenditure. Table 7 presents comparable estimates when excluding covariates from these models.

First of all, we conclude that there is a significant increase in the retirement probability of either the husband or the wife, upon reaching legal retirement age (720 months). In particular, the husband's retirement probability increases by 0.22 when he turns 60 estimating the model on sample A (see column 1 of Table 2) and by 0.17 estimating the model on sample B (see column 2 of Table 2). The wife retirement probability increases by a comparable amount when she turns 60 (720 months), and precisely, by 0.23 (see column 2 of Table 2) -we only 
estimate the model for the wife using sample B as sample A also include housewives for whom the probability of retirement is not defined.

These estimates are generally robust to dropping other covariates from the model (see Table 2) or restricting the sample boundaries on the two sides of the age discontinuity (see Table 3 ). However, notice that the cross-effect of spousal retirement (instrumented with the dummy for the spouse turning 60) on the own retirement probability is not significant for any of the specifications. This may suggest that spouses may not always time their retirement closely together, as also argued in recent work by Pollak (2013). ${ }^{9}$

We find no significant effect of either partner's retirement on total household consumption for any of the specification and sample cuts used (see Table 4). However, we find that retirement of the husband reduces total household expenditure - this effect is significant though only at the 10 percent level- when considering the most parsimonious specification that excludes covariates other than age (see Tables 7 and 8) and the larger sample that includes other inactive women (see Section 2 on sample selection). Generally, most of the covariates we control for are statistically significant and in the expected direction (though we do not discuss them here for conciseness). In particular, children leaving home have a negative and significant effect on non-durable consumption.

We conclude that retirement of the husband reduces significantly food expenditure when considering the larger sample that also includes couples with a housewife (see the first column of results in Tables 5 and 7). This is in line with the findings in the earlier studies that included all households in the analysis and focused on retirement of the head of the household. In particular, food consumption drops for this sample (sample A of Section 2) by about 18 per cent which is a very sizable drop (see Table 5). This effect is robust to dropping covariates from the model (see Table 7). However, when restricting the sample on the two sides of the age discontinuity, the drop in food consumption stays significant only in the specification that excludes covariates other than age (see Table 8). Because restricting the sample to couples in which both partners participated actively in the labor market lead to a non-significant drop in food expenditure upon retirement of the husband, this suggests perhaps that employment of the wife sheds the household from cutting down on food consumption when the husband retires, thus, protecting the household from experiencing financial hardship.

\footnotetext{
${ }^{9}$ See for example, Hurd, 1990, for an account of joint retirement in the USA.
} 
Retirement of the husband is also found to reduce significantly household clothing expenditure for all specifications and sample cuts (see Tables 6, 7 and 8). In particular, clothing expenditure drops by between 831 and 968 Euros per year when the husband retires (see columns 1 and 3 of Table 6). Because average clothing consumption for the couples in which both partners are aged 55 to less than 60 (in these couples partners' age is such that they are both very close to the age discontinuity which is the usual reference group to interpret the estimates of the model in RD analysis) is equal to 1600 euro per year, this represents a dramatic drop in clothing by between 52 and 60 per cent. This might be partly explained by the drop in work-related clothing expenditure. Moreover, older people may not need to buy clothes so frequently has younger people do. Retirement of the wife though has no effect on clothing (or food) expenditure, which is somewhat puzzling. Perhaps the husband is more likely to hold a job that requires expensive formal clothing than the wife is. Another concurring explanation might be that the husband is the main earner in the household -and often also the first to retire- and thus household clothing expenditure reacts dramatically to his retirement but not to hers.

Finally, we estimated the same models as in Tables 4, 5 and 6, restricting the analysis couples in which each partner was either employed or retired (sample B) allowing first, only for retirement of the husband, next, only for retirement of the wife, and, finally, for either partner's retirement. Under any of these specification, there is no significant drop in food consumption upon retirement of the husband (see Appendix Tables A, B and C), thus confirming earlier findings that food consumption falls upon male retirement only when we include couples in which the wife is a housewife in the sample (see Table 5). However, since sample A (which includes also couples with a housewife) is much larger than sample B, this difference in significance of the estimated effect of retirement on household food expenditure across the two samples could possibly also be explained by sample size, something we cannot check with the data to hand.

In terms of size, our estimates of the effect of husband's retirement on household total consumption are large though not significant statistically. Battistin et al. (2009) find that nondurable consumption drops by 9.8 per cent upon retirement of the head of the household significant only at the ten per cent level though, using data for Italy. Hurst (2013) report that spending on clothing falls by 18 per cent and food expenditure drops by 7 per cent upon retirement using American data. Thus, the drop in clothing expenditure is between two and three times as large as that in food expenditure in the USA, which is also what we find for 
France. Generally, however, the estimated size of the drop in either food or clothing consumption upon husband's retirement is much larger in our data than reported in earlier studies for the USA. This could be explained by the fact that on average the earnings distribution is more compressed in France than the USA (a well-documented fact, see for example OECD, 1998).

\section{Conclusions}

Earlier studies concluded that household expenditure and especially food and clothing consumption drop dramatically at retirement and that this is at least partly explained by increased home production, coupled with a reduction in work-related expenditure, and adult children leaving the parental home. However, only retirement of the head of the household has been taken into account in the earlier consumption literature to date. Here we study changes in household consumption when either partner retires from market work, distinguishing 'dual-earners' from couples in which the wife may be inactive, say a housewife. Moreover, this is the first study that investigates the drop in consumption upon retirement for France.

To identify the effect of each partner's retirement on household consumption, we exploit the legislation in France that sets 60 as the earliest retirement age for most workers. This creates a discontinuity in the probability of retirement as a function of age that enables us to apply a regression discontinuity approach. We use a fuzzy regression discontinuity approach to allow for the fact that some individuals may retire a little earlier than 60 and others a little later due to different sector of employment rules.

We use data drawn from the French Consumption Budget Survey which collected two weeks expenditure diary to study the effect of each partner's retirement on household non-durable consumption. In the data age is collected in months and thus we assume that it is measured continuously. We find that the individual retirement probability increases by roughly 0.20 upon reaching legal retirement age. In line with earlier studies, we find a significant and large drop in food expenditure and clothing expenditure upon retirement of the husband. However, when dropping couples in which the wife is a 'housewife' from the sample, the effect of the husband's retirement on food consumption becomes statistically insignificant. This suggests that employment of the wife's sheds the household from financial hardship. 
Only the drop in clothing expenditure is significant upon retirement of the husband for all sample cuts considered and this is likely to be explained by a reduction in work-related clothing expenditure that was also documented in earlier studies. However, we find no evidence that clothing expenditure drops upon retirement of the wife. This may be due to the fact that the husband is the main earner. It may also be that the husband is more likely to be employed in a job that requires more expensive formal clothing on average than the wife is.

Finally, the size of our estimates of the drop in food consumption and clothing consumption upon male retirement is much larger than those found in earlier studies. This could be explained by the fact that the earnings distribution in France is much more compressed than in the United States, a well-documented fact.

\section{References}

Aguiar, Mark, and Eric Hurst, 2013, "Deconstructing Life Cycle Expenditure", Journal of Political Economy, 121 (3): 437-492.

Aguiar, Mark, and Eric Hurst, 2007, "Life-Cycle Prices and Production", American Economic Review, 97(5): 1533-1559.

Aguiar, Mark and Erik Hurst, 2005, 'Consumption vs Expenditure', Journal of Political Economy 113, 5 (October): 919-948.

Apps,Patricia, and Ray Rees (2010), "Family labor supply, taxation and saving in an imperfect capital market," Review of Economics of the Household, vol. 8(3), p 297-323.

Apps, Patricia and Ray Rees (1997), "Collective Labor Supply and Household Production", Journal of Political Economy, vol. 105(1), pages 178-90.

Banks, James, Richard Blundell, and Sarah Tanner (1998), "Is There a Retirement Savings Puzzle?" American Economic Review, 88(4), 769 - 788.

Battistin, Erich, Agar Brugiavini, Enrico Rettore and Guglielmo Weber (2009), "The Retirement Consumption Puzzle: Evidence from a Regression Discontinuity ApproachAmerican Economic Review,99(5), 2209-2226.

Blanchet, Didier and Louis-Paul Pele (1997), Social Security and Retirement in France, NBER Working Paper No. 6214.

Bloemen, Hans and Stancanelli, Elena (2013), "Toyboys or Supergirls ?An analysis of partners' employment outcomes when she outearns him", Review of the Economics of the Household, forthcoming.

Card, David, Carlos Dobkin and Nicole Maestas (2009), "Does Medicare Save Lives? Quarterly Journal of Economics, 124(2), 597-636. 
Card, David, Carlos Dobkin and Nicole Maestas (2004), "The Impact of Nearly Universal Insurance Coverage on Health Care Utilization and Health: Evidence from Medicare", NBER Working Paper 10365, March.

Donni, Olivier and Nicolas Moreau (2007), "Collective Labor Supply: A Single-Equation Model and Some Evidence from French Data, Journal of Human Resources, 42, 214-246.

Duguet, Emanuel and Veronique Simonnet (2007), "Labor market participation in France: an asymptotic least squares analysis of couples' decisions," Review of Economics of the Household, vol. 5(2), 159-179.

Fisher, Jonathan, David Johnson, Joseph Marchand, Timothy Smeeding, and Barbara Boyle Torrey (2008), "The Retirement Consumption Conundrum: Evidence From a Consumption Survey", Economics Letters, 99, 482-85.

Gustman, Alan and Thomas Steinmeier (2009), "Integrating Retirement Models," NBER Working Paper 15607, December.

Gustman, Alan and Thomas Steinmeier (2000), "Retirement in Dual-Career Families: A Structural Model," Journal of Labor Economics, 18, 503-545.

Hairault, Jean-Olivier, Francois Langot and ThepthidaSopraseuth (2010), "Distance to Retirement and Older Workers' Employment: The Case for Delaying the Retirement Age," Journal of the European Economic Association, MIT Press, vol. 8(5), pages 1034-1076, 09.

Hamermesh, Daniel S. 1984. "Consumption During Retirement: The Missing Link in the Life-Cycle." Review of Economics and Statistics, 66(1): 1-7.

Hurd, Michael (1990), "The Joint Retirement Decision of Husbands and Wives," in: Issues in the Economics of Aging, David Wise (ed.), National Bureau of Economic Research, pp. 231258.

Hurd, Michael D. and Susann Rohwedder, 'Time Use in the Older Population', RAND WP WR-463, January 2007.

Hurd, Michael D. and Susann Rohwedder, 'The Retirement Consumption Puzzle: Actual Spending Change in Panel Data', April 2008, NBER Working Paper No. 13929

Hurst, Eric. 2008. "The Retirement of a Consumption Puzzle." NBER Working Paper 13789.

Imbens, Guido and Thomas Lemieux (2007), "Regression discontinuity design: a guide to practice", Journal of Econometrics, 142, 615-635.

Lee, David S. and Thomas Lemieux, "Regression Discontinuity Designs in Economics,"Journal of Economic Literature, 48 (2010), 281-355.

Lundberg, Shelly, Richard Startz and Stephen Stillman (2003), "The Retirement-Consumption Puzzle: A Marital Bargaining Approach", Journal of Public Economics, 87(5-6), 1199-1218.

McCrary Justin, "Manipulation of the Running Variable in the Regression Discontinuity Design:A Density Test," Journal of Econometrics, 142 (2008), pp. 698-714. 
Miniaci, Raffaele, Chiara Monfardini, and Guglielmo Weber (2010), "How does consumption change upon retirement?", Empirical Economics, 38, 257-280.

OECD, Employment Outlook, 1998, OECD, Paris.

Pollak, Robert A. (2013), "Labor Supply and Claiming Social Security Benefits: A Couples' Perspective", unpublished, mimeo.

Rapoport, Benoit, Catherine Sofer, and Anne Solaz (2011), "Household Production in a Collective Model: Some New Results", Journal of Population Economics, vol 24 n¹, p 2345.

Rizavi Salman, and Catherine Sofer (2009), "Women's relative position and the division of household work: A study of French couples" European Journal of Social Systems, vol 22, $\mathrm{n}^{\circ} 2, \mathrm{p} 13-26$.

Sédillot, B. and E. Walraet, (2002), "La cessation d'activité au sein des couples: y a-t-il interdépendance des choix?", Economie et Statistique, 357-358

Stancanelli, Elena G.F. and Arthur Van Soest (2012), "Retirement and Home Production: A Regression Discontinuity approach," American Economic Review, Papers and Proceedings, 102, 600-606.

Stewart, Jay, (2009). Tobit or Not Tobit? IZA DP 4588.

van der Klaauw, Wilbert (2008), "Regression-Discontinuity Analysis: A Survey of Recent Developments in Economics, Labour, 22(2), 219-245. 

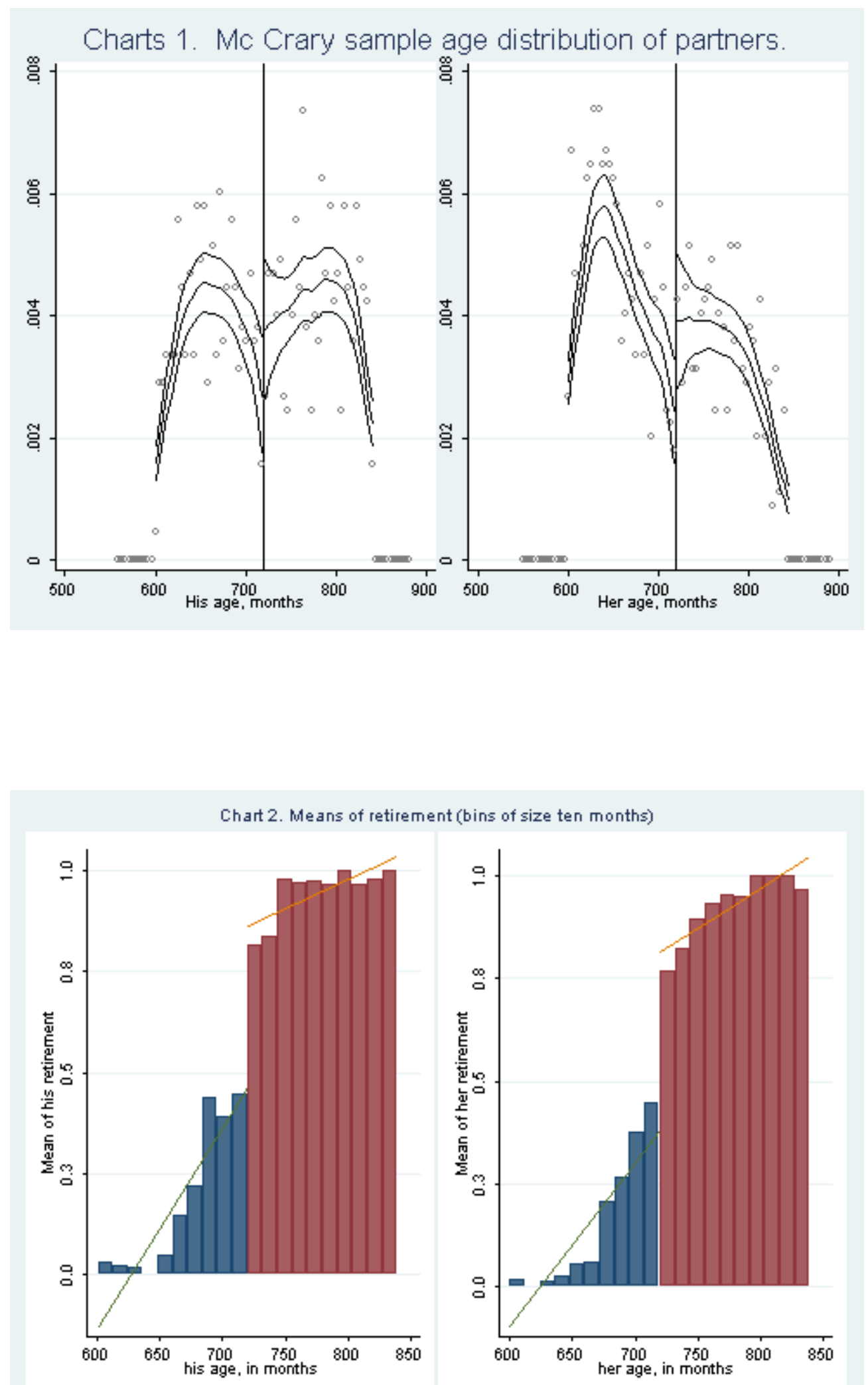
Charts 3. Means of expenditure by age (bins of size ten months)
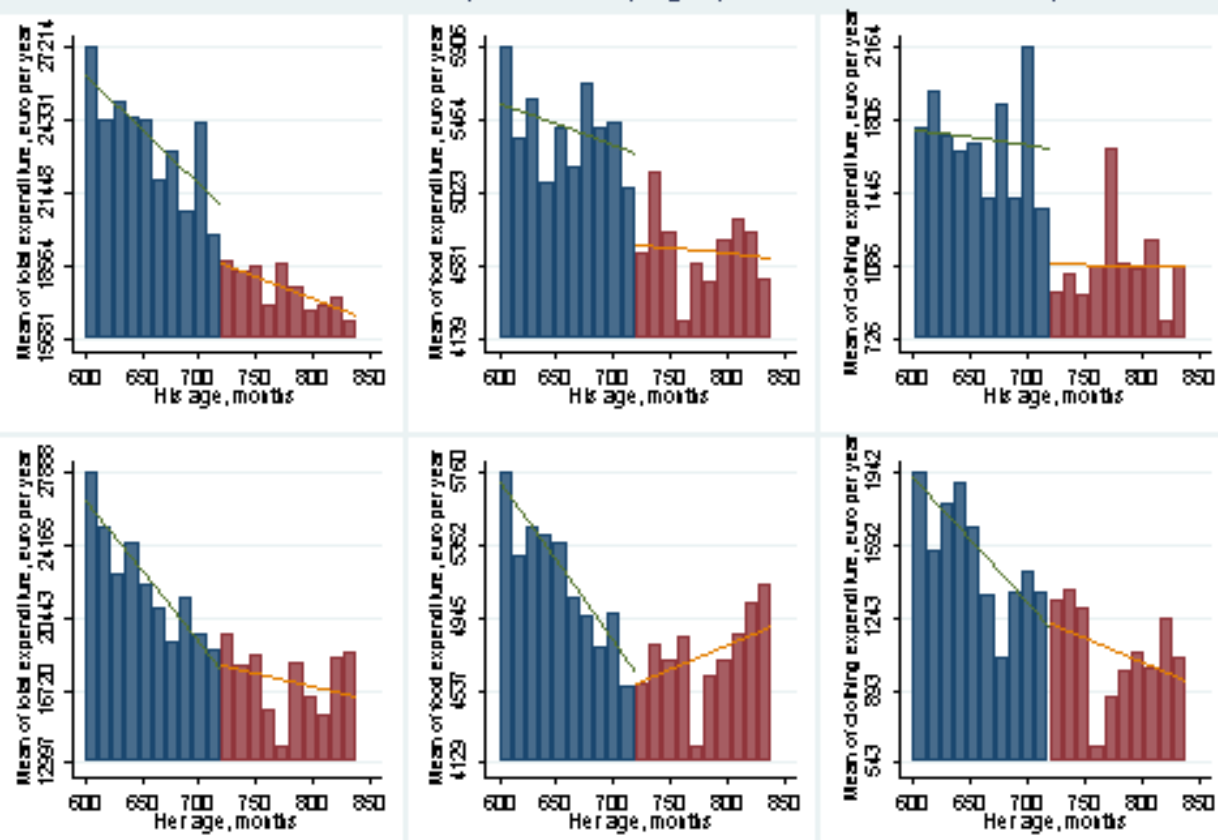
Chart 4. Predicted retirement probabilities as a function of covariates other than age.
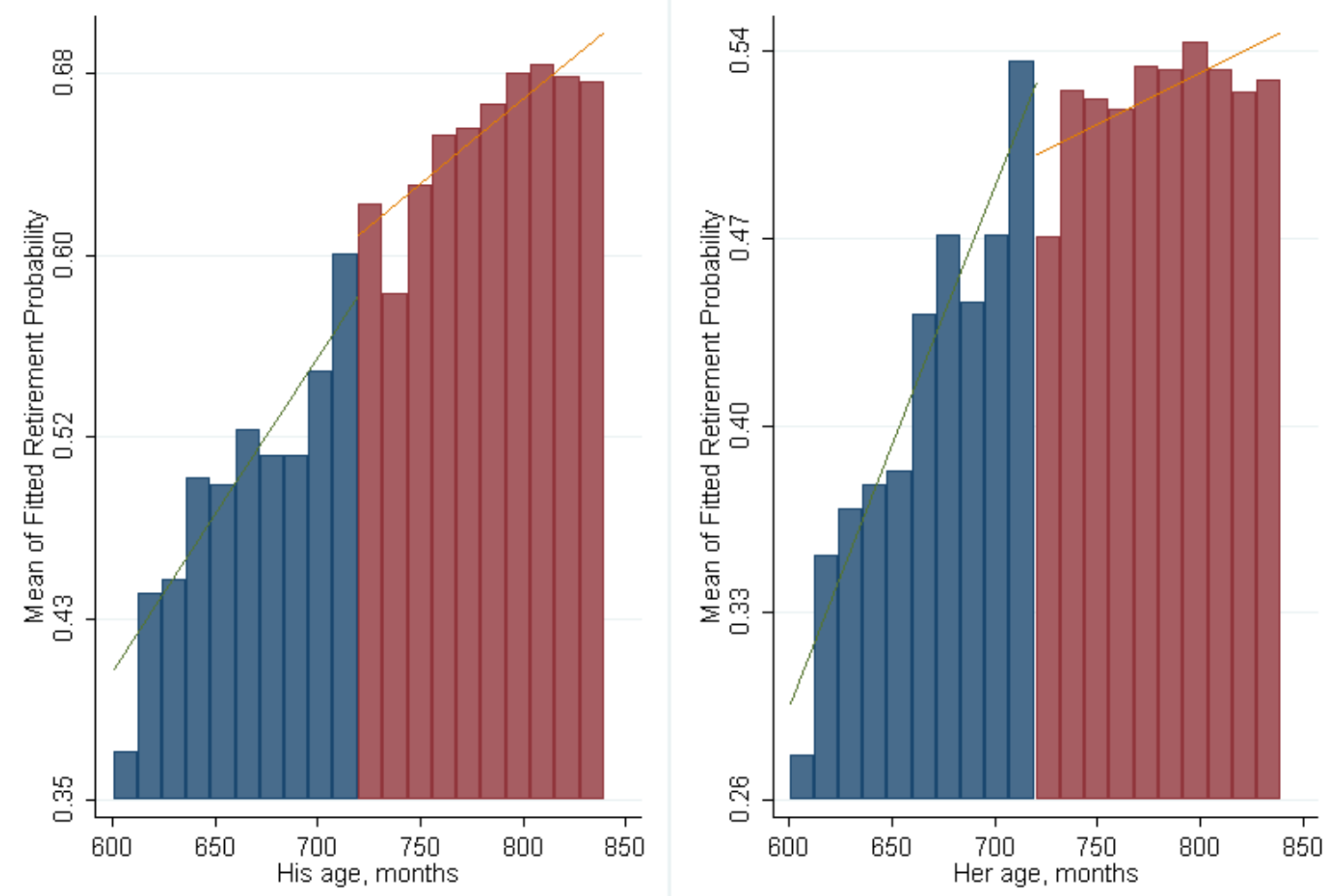
Chart 5. Discontinuities in retirement probabilities

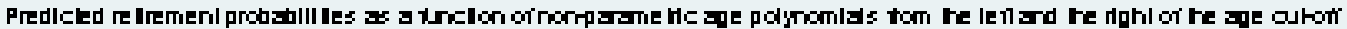
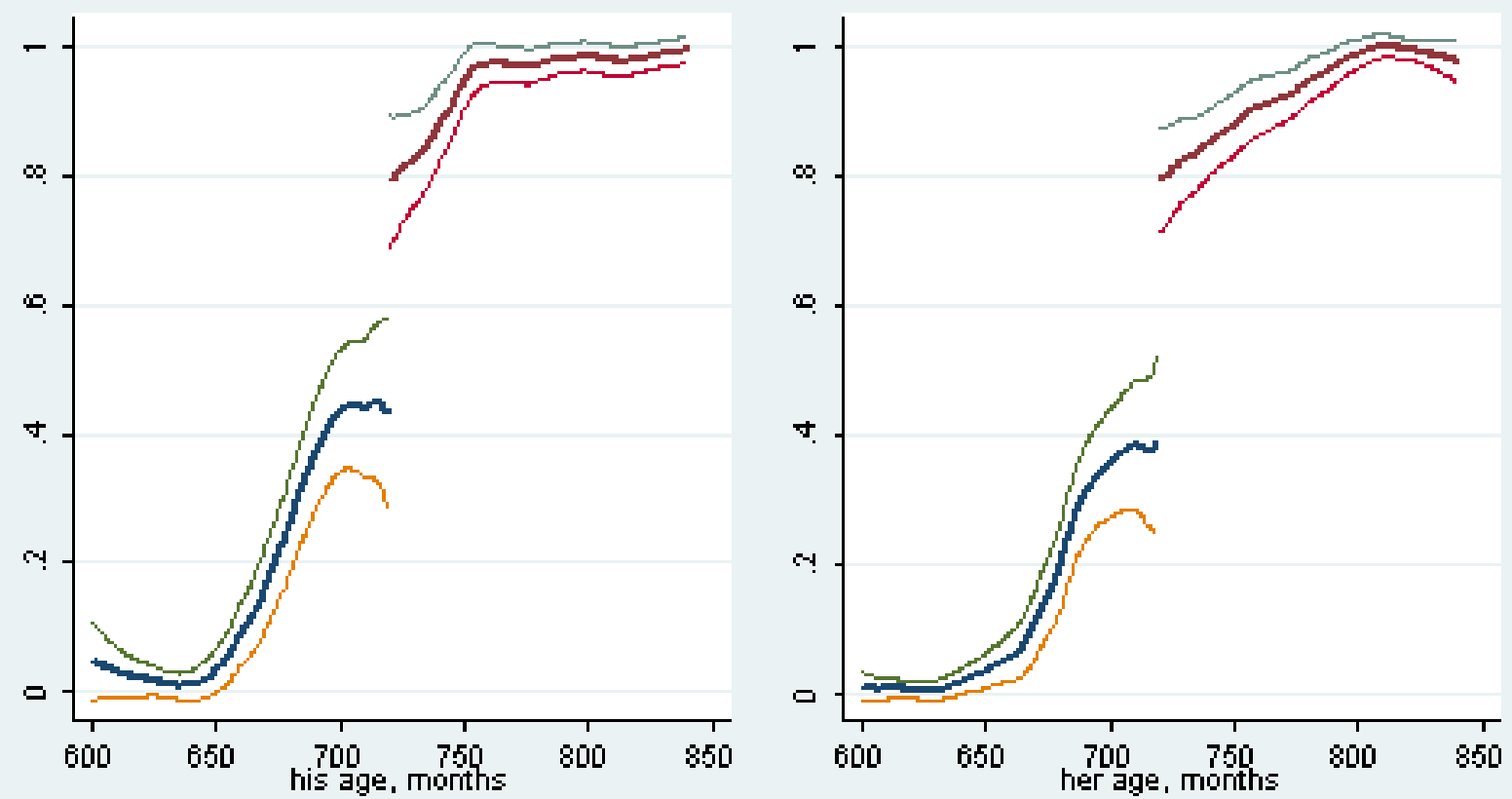

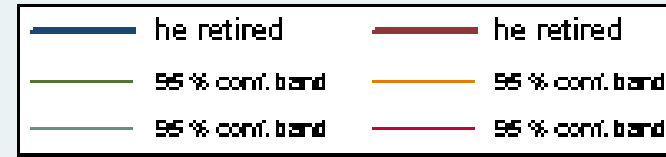

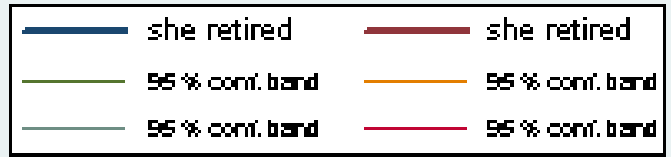


Chart 6 . Discontinuity in household expenditure at partners' age cut-off

Household food and total expenditure, predicted as a function of age polynomials from the right and the left of the age cutoff.
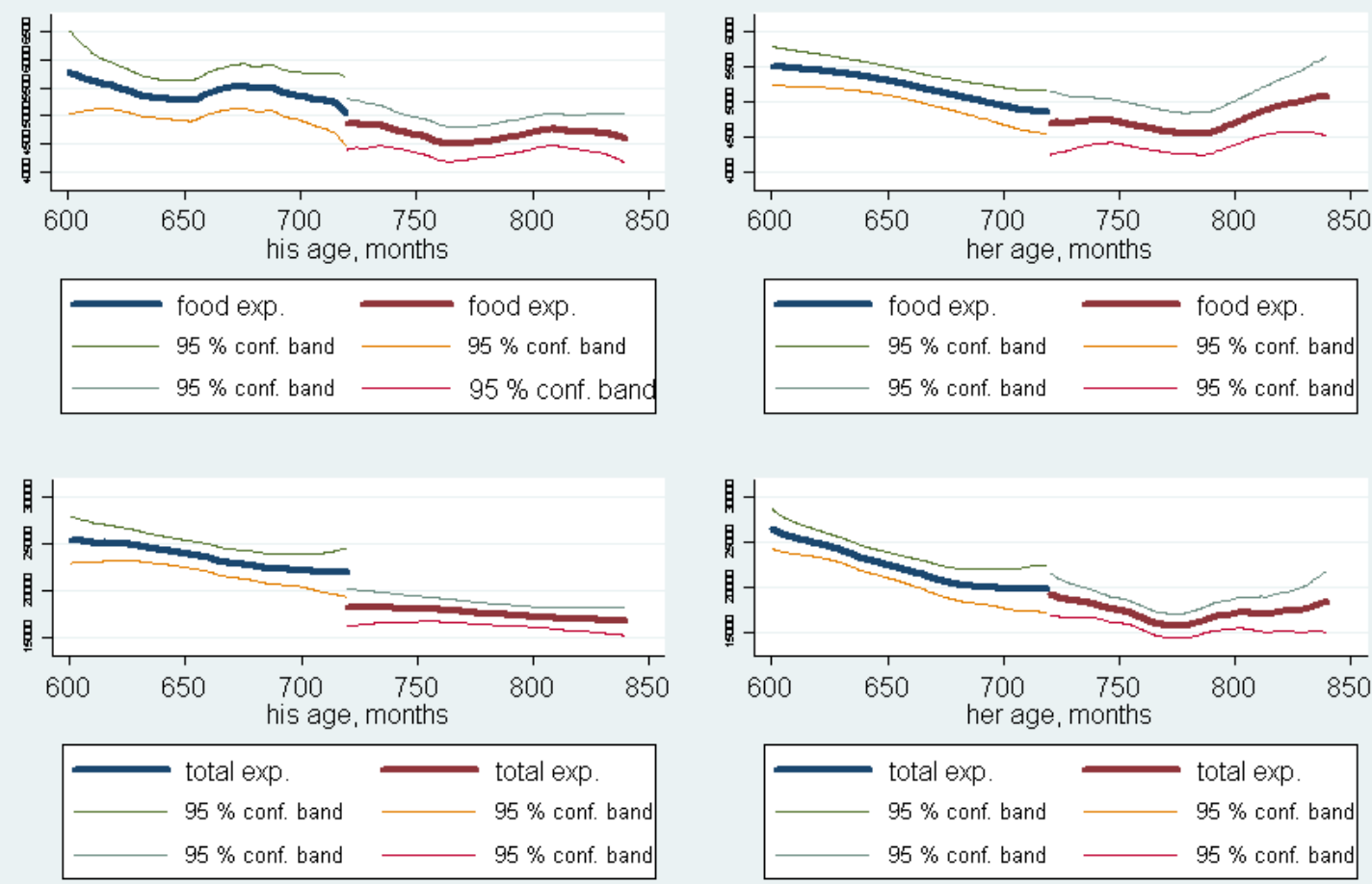
Chats 7 . Discontinuity in household clothing expenditure at partners age cut-off
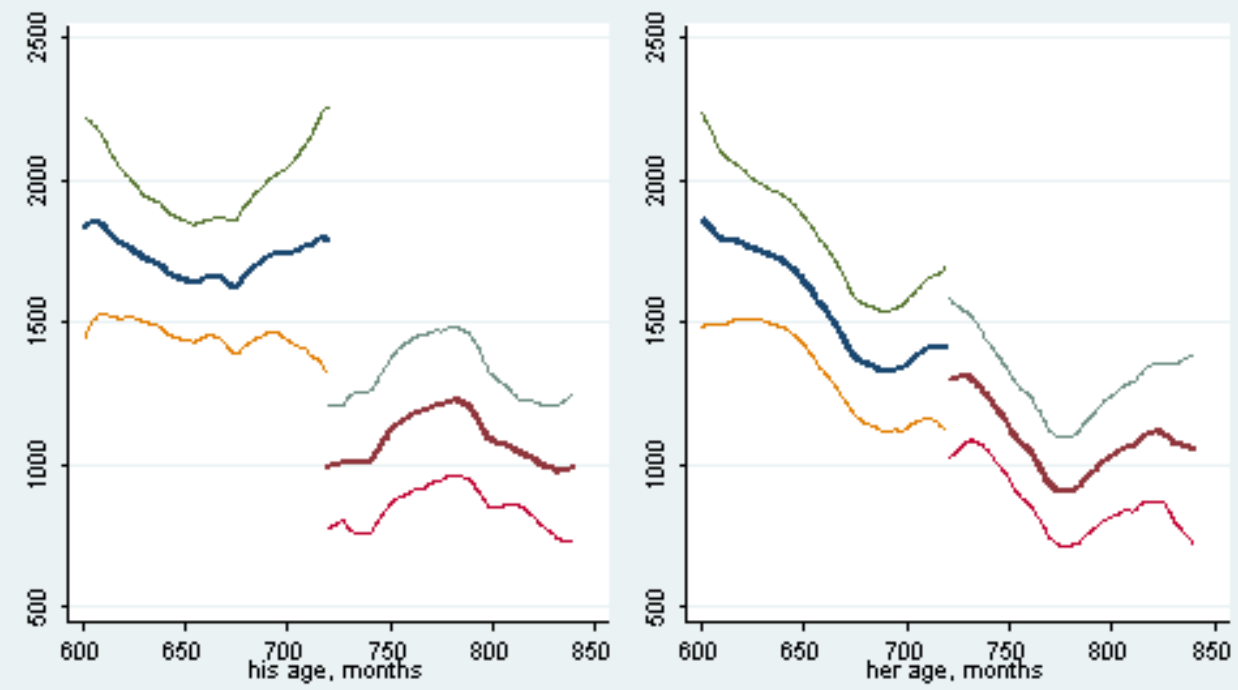

- retired $<60$, predieted- retired $>60$, prestict - she retired $<60$, ppedieteche retired $>60$, predi $95 x$ conf. band $-95 \%$ conf. band $95 \%$ cont. band $-95 \%$ conf. band 
Table 1. Household Consumption Survey 2000-2001. Descriptive Statistics

\begin{tabular}{|c|c|c|c|c|}
\hline \multirow{4}{*}{ Age yrs. } & \multicolumn{2}{|c|}{ Sample A } & \multicolumn{2}{|c|}{ Sample B } \\
\hline & Male & Female & Male & Female \\
\hline & 60.40 & 58.31 & 60.31 & 58.73 \\
\hline & $(5.56)$ & $(5.41)$ & $(5.71)$ & $(5.70)$ \\
\hline \multirow[t]{2}{*}{ Age $>=60$} & 0.53 & 0.38 & 0.52 & 0.42 \\
\hline & $(0.50)$ & $(0.49)$ & $(0.50)$ & $(0.49)$ \\
\hline \multirow[t]{2}{*}{ Retired } & 0.59 & 0.31 & 0.58 & 0.45 \\
\hline & $(0.49)$ & $(0.46)$ & $(0.49)$ & $(0.50)$ \\
\hline \multirow[t]{2}{*}{ French } & 0.93 & 0.94 & 0.94 & 0.95 \\
\hline & $(0.25)$ & $(0.24)$ & $(0.23)$ & $(0.20)$ \\
\hline \multirow[t]{2}{*}{ Middle Tech. } & 0.26 & 0.17 & 0.26 & 0.17 \\
\hline & $(0.44)$ & $(0.37)$ & $(0.44)$ & $(0.37)$ \\
\hline \multirow[t]{2}{*}{ Middle } & 0.09 & 0.13 & 0.09 & 0.13 \\
\hline & $(0.28)$ & $(0.34)$ & $(0.29)$ & $(0.33)$ \\
\hline \multirow[t]{2}{*}{ High tech. } & 0.05 & 0.03 & 0.05 & 0.03 \\
\hline & $(0.21)$ & $(0.17)$ & $(0.22)$ & $(0.16)$ \\
\hline \multirow[t]{2}{*}{ High School } & 0.06 & 0.08 & 0.06 & 0.10 \\
\hline & $(0.24)$ & $(0.27)$ & $(0.24)$ & $(0.29)$ \\
\hline \multirow[t]{2}{*}{ College short } & 0.05 & 0.07 & 0.06 & 0.09 \\
\hline & $(0.22)$ & $(0.25)$ & $(0.23)$ & $(0.28)$ \\
\hline \multirow[t]{4}{*}{ College } & 0.12 & 0.07 & 0.12 & 0.08 \\
\hline & $(0.32)$ & $(0.25)$ & $(0.32)$ & $(0.27)$ \\
\hline & Househol & acteristics & Househ & icteristics \\
\hline & & & & \\
\hline \multirow{2}{*}{$\begin{array}{l}\text { No. children at } \\
\text { home }\end{array}$} & & & & \\
\hline & & & & \\
\hline \multirow[t]{2}{*}{$\begin{array}{l}\text { No. children left } \\
\text { home }\end{array}$} & & & & \\
\hline & & & & \\
\hline \multirow[t]{2}{*}{ Married } & & & & \\
\hline & & & & \\
\hline \multirow[t]{2}{*}{ Region Paris } & & & & \\
\hline & & & & \\
\hline \multirow[t]{2}{*}{$\begin{array}{l}\text { Total } \\
\text { consumption }\end{array}$} & & & & \\
\hline & & & & \\
\hline \multirow[t]{2}{*}{ Food } & & & & \\
\hline & & & & \\
\hline \multirow[t]{2}{*}{ Clothing } & & & & \\
\hline & & & & \\
\hline Number of obs. & 156 & ples & & les \\
\hline
\end{tabular}


Table 2.Results of estimation of the first stage regressions for the two models.

\begin{tabular}{llll}
\hline a) First Stage Regressions: model including all covariates & & \\
& & (2) Both partners retire \\
& & He retires & She retires \\
He is $60=\mathrm{Dm}$ & $0.226^{* * *}$ & $0.168^{* *}$ & 0.053 \\
& $(0.065)$ & $(0.084)$ & $(0.064)$ \\
Sheis $60=\mathrm{Df}$ & & -0.003 & $0.230^{* *}$ \\
& & $(0.059)$ & $(0.083)$
\end{tabular}

b) First Stage Regressions: model without covariates other than age

$\begin{array}{ll}\text { (1) Male retirement } & \text { (2) Both partners retire }\end{array}$

$\begin{array}{ll}\text { He is } 60=\mathrm{Dm} & 0.237 * * * \\ & (.066) \\ \mathrm{Dm} \times(\text { Hisage }-60) & -0.088^{* * *} \\ & (0.025) \\ \mathrm{Dm} \times(\text { His age-60) })^{2} & -0.012 * * * \\ & (0.002)\end{array}$

He retires She retires

$0.182 * * \quad 0.044$

$(0.085) \quad(0.063)$

$-0.075 * * \quad-0.0002$

$(0.032) \quad(0.026)$

$-0.013 * * * \quad 0.003$

$(0.003) \quad(0.002)$

Sheis $60=\mathrm{Df}$

$-0.014 \quad 0.226^{* *}$

$(0.060) \quad(0.084)$

Df $\times($ Her age- 60$)$

$0.028-0.074^{* *}$

$(0.026) \quad(0.031)$

Df $\times(\text { Her age- } 60)^{2}$

$-0.0001 \quad-0.012$ **

(0.002) $\quad(0.003)$

Number of obs.

1067

Standard errors in parentheses are robust to heteroskedasticity of unknown form. ${ }^{* * *} \mathrm{p}<0.01,{ }^{* *} \mathrm{p}<0.05,{ }^{*} \mathrm{p}<0.1$. Only selected coefficients are shown. 
Table 3. First Stage Regressions, restricting sample boundaries.

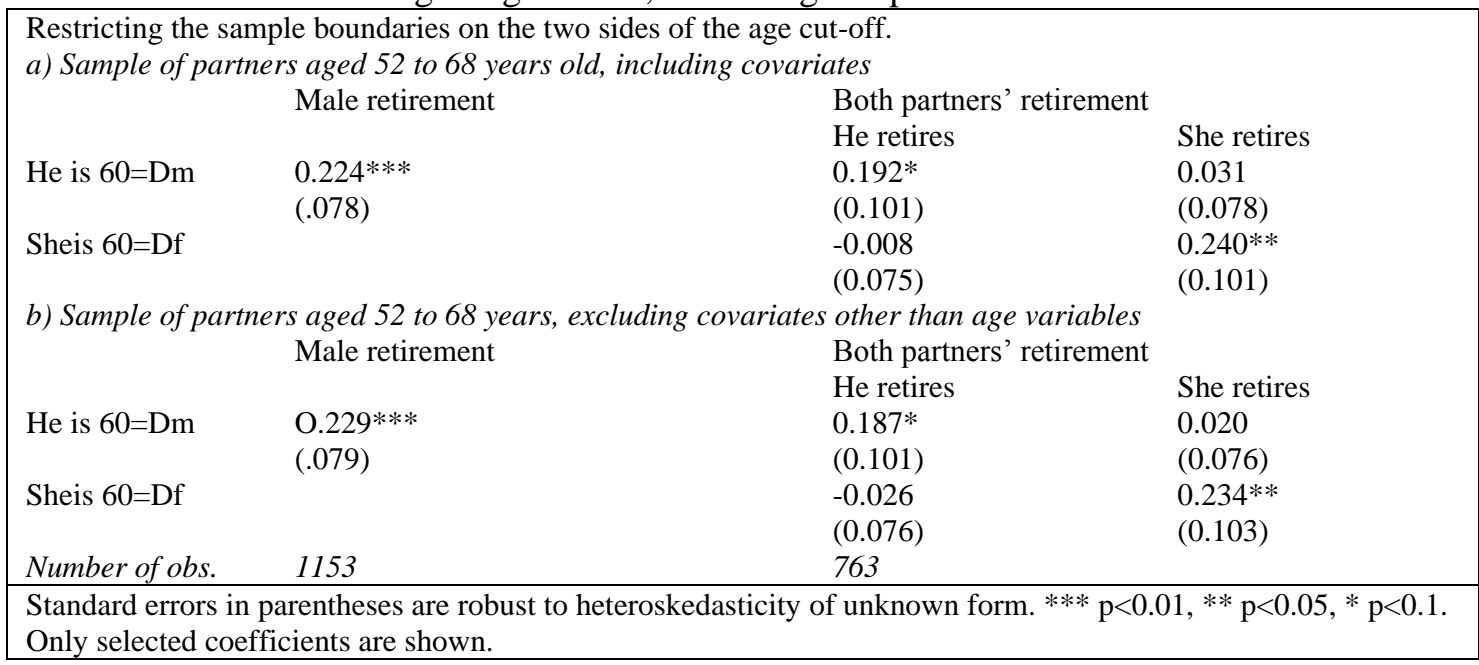


Table 4. The effect of retirement on total household consumption: IV models.

\begin{tabular}{|c|c|c|}
\hline & 1) Male retirement & 2) Both partners' retirement \\
\hline Mean Household Consumption for age 55-59 & 20828 & 22020 \\
\hline \multirow[t]{2}{*}{ He Retired } & -2266.97 & -2218 \\
\hline & $(2311.88)$ & $(3026)$ \\
\hline \multirow[t]{2}{*}{ She Retired } & & -353.3 \\
\hline & & (2749) \\
\hline \multirow[t]{2}{*}{ Number of children still at home } & $4716.05 * * *$ & $5774 * * *$ \\
\hline & $(498.36)$ & $(643.8)$ \\
\hline \multirow[t]{2}{*}{ Number of children left home } & $-607.63 * * *$ & -293.9 \\
\hline & $(169.04)$ & $(208.9)$ \\
\hline \multirow[t]{2}{*}{ He Intermed. Educ. Technical } & $2023.29 * * *$ & 431.8 \\
\hline & $(540.75)$ & $(692.1)$ \\
\hline \multirow[t]{2}{*}{ He Intermed. Educ. General } & $5687.99 * * *$ & $3075^{* * * *}$ \\
\hline & $(897.47)$ & $(993.6)$ \\
\hline \multirow[t]{2}{*}{ He High School, technical } & $4796.30 * * *$ & $2698^{* *}$ \\
\hline & $(946.32)$ & $(1081)$ \\
\hline \multirow[t]{2}{*}{ He High School, general } & $7845.37 * * *$ & $3605^{* * *}$ \\
\hline & $(1136.96)$ & $(1309)$ \\
\hline \multirow[t]{2}{*}{ He College short degree } & $9404.09 * * *$ & $4727 * * *$ \\
\hline & $(1234.69)$ & $(1457)$ \\
\hline \multirow[t]{2}{*}{ He College and more } & $13992.01 * * *$ & $7469 * * *$ \\
\hline & $(1233.15)$ & $(1888)$ \\
\hline \multirow{2}{*}{ SheIntermed. Educ. Technical } & & $2442 * * *$ \\
\hline & & $(747.9)$ \\
\hline \multirow[t]{2}{*}{ SheIntermed. Educ. General } & & $4471 * * *$ \\
\hline & & $(949.8)$ \\
\hline \multirow{2}{*}{ She High School, technical } & & $5012 * *$ \\
\hline & & $(2397)$ \\
\hline \multirow[t]{2}{*}{ She High School, general } & & $5598 * * *$ \\
\hline & & $(1159)$ \\
\hline \multirow[t]{2}{*}{ SheCollege short degree } & & $7272 * * *$ \\
\hline & & $(1278)$ \\
\hline \multirow[t]{2}{*}{ SheCollege and more } & & $9959 * * *$ \\
\hline & & (2096) \\
\hline \multirow[t]{2}{*}{ He French } & $3579.73 * * *$ & $3371 * *$ \\
\hline & $(1034.55)$ & $(1516)$ \\
\hline \multirow[t]{2}{*}{ She French } & & -307.0 \\
\hline & & (1904) \\
\hline \multirow[t]{2}{*}{ Married } & $-2795.84^{*}$ & -2703 \\
\hline & $(1538.44)$ & $(1883)$ \\
\hline \multirow[t]{2}{*}{ Inner Paris } & $3602.71 * * *$ & $4056^{* * * *}$ \\
\hline & $(393.43)$ & $(987.4)$ \\
\hline \multirow[t]{2}{*}{ Region of Paris } & 688.70 & $1632 * *$ \\
\hline & $(644.53)$ & $(777.4)$ \\
\hline Number of obs. & 1567 & 1067 \\
\hline
\end{tabular}


Table 5. The effect of retirement on household food consumption: IV models.

\begin{tabular}{|c|c|c|}
\hline Mean food Consumption age 55-59 & $\begin{array}{l}\text { Male retirement } \\
5275\end{array}$ & $\begin{array}{l}\text { Both partners' retirement } \\
5441\end{array}$ \\
\hline He Retired & $\begin{array}{l}-992.78 * * \\
(485.12)\end{array}$ & $\begin{array}{l}-992.4 \\
(643.4)\end{array}$ \\
\hline She Retired & & $\begin{array}{l}-283.4 \\
(573.3)\end{array}$ \\
\hline Number of children still at home & $\begin{array}{l}735.56^{* * * *} \\
(108.65)\end{array}$ & $\begin{array}{l}972.8 * * * \\
(132.5)\end{array}$ \\
\hline Number of children left home & $\begin{array}{l}-70.00 * \\
(40.73)\end{array}$ & $\begin{array}{l}-48.03 \\
(47.63)\end{array}$ \\
\hline He Intermed. Educ. Tech. & $\begin{array}{l}251.11^{*} \\
(130.84)\end{array}$ & $\begin{array}{l}69.17 \\
(160.6)\end{array}$ \\
\hline He Intermed. Educ. General & $\begin{array}{l}506.28 * * \\
(219.29)\end{array}$ & $\begin{array}{l}-11.30 \\
(272.0)\end{array}$ \\
\hline He High School, technical & $\begin{array}{l}500.46 * * \\
(224.91)\end{array}$ & $\begin{array}{l}146.4 \\
(266.3)\end{array}$ \\
\hline He High School, general & $\begin{array}{l}1050.98 * * * \\
(264.16)\end{array}$ & $\begin{array}{l}541.6^{*} \\
(322.5)\end{array}$ \\
\hline He College short degree & $\begin{array}{l}802.16^{* * *} \\
(272.26)\end{array}$ & $\begin{array}{l}177.5 \\
(324.4)\end{array}$ \\
\hline He College and more & $\begin{array}{l}1283.16^{* * *} \\
(226.51)\end{array}$ & $\begin{array}{l}387.2 \\
(373.9)\end{array}$ \\
\hline She Intermed. Educ. Technical & & $\begin{array}{l}394.5^{* *} \\
(176.7)\end{array}$ \\
\hline She Intermed. Educ. General & & $\begin{array}{l}736.8 * * * \\
(220.8)\end{array}$ \\
\hline She High School, technical & & $\begin{array}{l}785.9 * * \\
(396.2)\end{array}$ \\
\hline She High School, general & & $\begin{array}{l}575.0 * * \\
(278.9)\end{array}$ \\
\hline She College short degree & & $\begin{array}{l}1361 * * * \\
(320.2)\end{array}$ \\
\hline She College and more & & $\begin{array}{l}1110 * * * \\
(399.2)\end{array}$ \\
\hline He French & $\begin{array}{l}564.25 * * \\
(231.41)\end{array}$ & $\begin{array}{l}423.1 \\
(360.9)\end{array}$ \\
\hline She French & & $\begin{array}{l}307.9 \\
(367.1)\end{array}$ \\
\hline Married & $\begin{array}{l}199.38 \\
(302.28)\end{array}$ & $\begin{array}{l}152.8 \\
(362.0)\end{array}$ \\
\hline Inner Paris & $\begin{array}{l}368.03 * \\
(192.46)\end{array}$ & $\begin{array}{l}492.9 * * \\
(228.6)\end{array}$ \\
\hline Other Region of Paris & $\begin{array}{l}29.59 \\
(138.75)\end{array}$ & $\begin{array}{l}161.5 \\
(165.2)\end{array}$ \\
\hline Number of obs. & 1567 & 1067 \\
\hline
\end{tabular}


Table 6. The effect of retirement on household clothing consumption: IV models

\begin{tabular}{|c|c|c|}
\hline Mean Clothing consumption 55-59 & $\begin{array}{l}\text { Male retirement } \\
1532\end{array}$ & $\begin{array}{l}\text { Both partners' retirement } \\
1603\end{array}$ \\
\hline He Retired & $\begin{array}{l}-830.99 * * \\
(328.26)\end{array}$ & $\begin{array}{l}-967.6^{* *} \\
(470.4)\end{array}$ \\
\hline She Retired & & $\begin{array}{l}-112.2 \\
(381.9)\end{array}$ \\
\hline Number of children still at home & $\begin{array}{l}224.60 * * * \\
(78.67)\end{array}$ & $\begin{array}{l}305.6^{* * * *} \\
(86.20)\end{array}$ \\
\hline Number of children left home & $\begin{array}{l}-58.69 * * \\
(26.09)\end{array}$ & $\begin{array}{l}-44.64 \\
(31.95)\end{array}$ \\
\hline He Intermed. Educ. Tech. & $\begin{array}{l}252.28 * * * \\
(72.79)\end{array}$ & $\begin{array}{l}127.3 \\
(90.18)\end{array}$ \\
\hline He Intermed. Educ. General & $\begin{array}{l}722.95 * * * \\
(142.00)\end{array}$ & $\begin{array}{l}528.0 * * * \\
(158.7)\end{array}$ \\
\hline He High School, technical & $\begin{array}{l}724.91 * * * \\
(180.47)\end{array}$ & $\begin{array}{l}548.1 * * * \\
(208.2)\end{array}$ \\
\hline He High School, general & $\begin{array}{l}838.83 * * * \\
(210.79)\end{array}$ & $\begin{array}{l}278.0 \\
(228.2)\end{array}$ \\
\hline He College short degree & $\begin{array}{l}806.98 * * * \\
(202.48)\end{array}$ & $\begin{array}{l}483.6^{* *} \\
(226.1)\end{array}$ \\
\hline He College and more & $\begin{array}{l}1338.43 * * * \\
(232.89)\end{array}$ & $\begin{array}{l}736.9 * * \\
(314.4)\end{array}$ \\
\hline She Intermed. Educ. Technical & & $\begin{array}{l}317.3 * * * \\
(113.2)\end{array}$ \\
\hline She Intermed. Educ. General & & $\begin{array}{l}444.5 * * * \\
(157.5)\end{array}$ \\
\hline She High School, technical & & $\begin{array}{l}439.2 \\
(268.8)\end{array}$ \\
\hline She High School, general & & $\begin{array}{l}545.8 * * * \\
(181.8)\end{array}$ \\
\hline She College short degree & & $\begin{array}{l}432.5^{* *} \\
(213.0)\end{array}$ \\
\hline She College and more & & $\begin{array}{l}956.2 * * \\
(385.2)\end{array}$ \\
\hline He French & $\begin{array}{l}335.01 * * \\
(141.56)\end{array}$ & $\begin{array}{l}374.2^{*} \\
(219.6)\end{array}$ \\
\hline She French & & $\begin{array}{l}12.10 \\
(259.4)\end{array}$ \\
\hline Married & $\begin{array}{l}-160.39 \\
(185.29)\end{array}$ & $\begin{array}{l}-153.0 \\
(185.0)\end{array}$ \\
\hline Inner Paris & $\begin{array}{l}356.06 * * * \\
(141.56)\end{array}$ & $\begin{array}{l}372.7 * * \\
(146.7)\end{array}$ \\
\hline Other Region of Paris & $\begin{array}{l}-13.96 \\
(119.06)\end{array}$ & $\begin{array}{l}58.35 \\
(134.5)\end{array}$ \\
\hline Number of obs. & 1567 & 1067 \\
\hline
\end{tabular}


Table 7. The effect of retirement on consumption: excluding covariates other than age variables

\begin{tabular}{|lll|}
\hline & Male retirement & Both partners' retirement \\
Effects on total consumption & & \\
He Retired & $-4454.57^{*}$ & -3187 \\
She Retired & $(2676.17)$ & $(3669)$ \\
& & 809.7 \\
Effects on food consumption & & $(3383)$ \\
He Retired & $-1221.83^{* *}$ & \\
& $(513.67)$ & -1021 \\
She Retired & & $(698.9)$ \\
Effects on clothing consumption & & -123.2 \\
He Retired & $-999.65^{* * *}$ & $(620.9)$ \\
& $(346.59)$ & $-1263 * * *$ \\
She Retired & & $(478.9)$ \\
Number of obs. & 1567 & 34.76 \\
\hline Robust standard errors in parentheses. $* * * \mathrm{p}<0.01, * * \mathrm{p}<0.05, * \mathrm{p}<0.1$. & $(417.2)$ \\
\hline
\end{tabular}


Table 8. Robustness checks

\begin{tabular}{|c|c|c|}
\hline \multicolumn{3}{|c|}{$\begin{array}{l}\text { Restricting the sample boundaries on the two sides of the age cut-off } \\
\text { a) Sample of partners aged } 52 \text { to } 68 \text { years, including covariates }\end{array}$} \\
\hline \multicolumn{3}{|c|}{ Total Household Consumption } \\
\hline He Retired & $\begin{array}{l}-3247.18 \\
(3244.21)\end{array}$ & $\begin{array}{l}-1261 \\
(4,231)\end{array}$ \\
\hline She Retired & & $\begin{array}{l}-2,548 \\
(3744)\end{array}$ \\
\hline \multicolumn{3}{|l|}{ Food Consumption } \\
\hline He Retired & $\begin{array}{l}-1111.25 \\
(718.88)\end{array}$ & $\begin{array}{l}-1519 \\
(1041)\end{array}$ \\
\hline She Retired & & $\begin{array}{l}216.6 \\
(849.3)\end{array}$ \\
\hline \multicolumn{3}{|l|}{ Clothing Consumption } \\
\hline He Retired & $\begin{array}{l}-1474.84 * * * \\
(501.51)\end{array}$ & $\begin{array}{l}-1673 * * \\
(745.8)\end{array}$ \\
\hline She Retired & & $\begin{array}{l}144.0 \\
(556.7)\end{array}$ \\
\hline \multicolumn{3}{|c|}{ b) Sample of partners aged 52 to 68 years, excluding covariates other than age variables } \\
\hline \multicolumn{3}{|c|}{ Total Household Consumption } \\
\hline He Retired & $\begin{array}{l}-6623.13^{*} \\
(3731.054)\end{array}$ & $\begin{array}{l}-4430 \\
(4842)\end{array}$ \\
\hline She Retired & & $\begin{array}{l}1522 \\
(4514)\end{array}$ \\
\hline \multicolumn{3}{|l|}{ Food Consumption } \\
\hline He Retired & $\begin{array}{l}-1290.72 * \\
(716.87)\end{array}$ & $\begin{array}{l}-1389 \\
(985.4)\end{array}$ \\
\hline She Retired & & $\begin{array}{l}599.8 \\
(878.2)\end{array}$ \\
\hline \multicolumn{3}{|l|}{ Clothing Consumption } \\
\hline He Retired & $\begin{array}{l}-1743.882 * * * \\
(520.7754)\end{array}$ & $\begin{array}{l}-1838 * * * \\
(695.0)\end{array}$ \\
\hline She Retired & & $\begin{array}{l}407.8 \\
(613.6)\end{array}$ \\
\hline Number of observations & 1153 & 763 \\
\hline
\end{tabular}

\section{Appendix}


Table A. The effect of retirement on total household consumption: estimation results for the sample of couples in which each partner is either employed or retired.

\begin{tabular}{|c|c|c|c|}
\hline & (1) & (2) & (3) \\
\hline \multirow[t]{2}{*}{ Mean Household Consumption for age 55-59 } & 22020 & 22020 & 22020 \\
\hline & $-3,127$ & & $-2,218$ \\
\hline He Retired & $(2,988)$ & & $(3,026)$ \\
\hline \multirow[t]{2}{*}{ She Retired } & & -936.6 & -353.3 \\
\hline & & $(2,937)$ & $(2,749)$ \\
\hline \multirow[t]{2}{*}{ Number of children still at home } & $5,903 * * *$ & $5,827 * * *$ & $5,774 * * *$ \\
\hline & $(663.1)$ & $(672.2)$ & $(643.8)$ \\
\hline \multirow[t]{2}{*}{ Number of children left home } & $-488.4 * *$ & -243.9 & -293.9 \\
\hline & $(204.6)$ & $(233.4)$ & $(208.9)$ \\
\hline \multirow[t]{2}{*}{ He Intermed. Educ. technical } & $1,571 * *$ & & 431.8 \\
\hline & $(687.2)$ & & $(692.1)$ \\
\hline \multirow[t]{2}{*}{ He Intermed. Educ. general } & $5,411 * * *$ & & $3,075 * * *$ \\
\hline & $(1,031)$ & & $(993.6)$ \\
\hline \multirow[t]{2}{*}{ He High School, technical } & $4,042 * * *$ & & $2,698 * *$ \\
\hline & $(1,178)$ & & $(1,081)$ \\
\hline \multirow[t]{2}{*}{ He High School, general } & $7,739 * * *$ & & $3,605 * * *$ \\
\hline & $(1,336)$ & & $(1,309)$ \\
\hline \multirow[t]{2}{*}{ He College short degree } & $8,654 * * *$ & & $4,727 * * *$ \\
\hline & $(1,392)$ & & $(1,457)$ \\
\hline \multirow[t]{2}{*}{ He College and more } & $13,977 * * *$ & & $7,469 * * *$ \\
\hline & $(1,542)$ & & $(1,888)$ \\
\hline \multirow[t]{2}{*}{ She Intermed. Educ. technical } & & $3,000 * * *$ & $2,442 * * *$ \\
\hline & & $(743.4)$ & $(747.9)$ \\
\hline \multirow[t]{2}{*}{ She Intermed. Educ. general } & & $5,913 * * *$ & $4,471 * * *$ \\
\hline & & $(1,040)$ & $(949.8)$ \\
\hline \multirow[t]{2}{*}{ She High School, technical } & & $6,981 * * *$ & $5,012 * *$ \\
\hline & & $(2,680)$ & $(2,397)$ \\
\hline \multirow[t]{2}{*}{ She High School, general } & & $8,077 * * *$ & $5,598 * * *$ \\
\hline & & $(1,073)$ & $(1,159)$ \\
\hline \multirow[t]{2}{*}{ She College short degree } & & $10,980 * * *$ & $7,272 * * *$ \\
\hline & & $(1,294)$ & $(1,278)$ \\
\hline \multirow[t]{2}{*}{ She College and more } & & $15,944 * * *$ & $9,959 * * *$ \\
\hline & & $(1,685)$ & $(2,096)$ \\
\hline \multirow[t]{2}{*}{ He French } & $3,103 * * *$ & & $3,371 * *$ \\
\hline & $(1,188)$ & & $(1,516)$ \\
\hline \multirow[t]{2}{*}{ She French } & & 2,273 & -307.0 \\
\hline & & $(1,589)$ & $(1,904)$ \\
\hline \multirow[t]{2}{*}{ Married } & $-3,692^{*}$ & $-2,191$ & $-2,703$ \\
\hline & $(1,935)$ & $(1,957)$ & $(1,883)$ \\
\hline \multirow[t]{2}{*}{ Inner Paris } & $4,282 * * *$ & $4,438 * * *$ & $4,056 * * *$ \\
\hline & $(1,046)$ & $(1,057)$ & (987.4) \\
\hline \multirow[t]{2}{*}{ Region of Paris } & $1,391 *$ & 1,459 & $1,632 * *$ \\
\hline & (780.9) & (939.5) & (777.4) \\
\hline Observations & 1067 & 1067 & 1067 \\
\hline
\end{tabular}


Table B. The effect of retirement on household food consumption: estimation results for the sample of couples in which each partner is either employed or retired.

\begin{tabular}{|c|c|c|c|}
\hline \multirow[b]{2}{*}{ Mean food Consumption age 55-59 } & (1) & (2) & (3) \\
\hline & 5441 & 5441 & 5441 \\
\hline \multirow[t]{2}{*}{ He Retired } & $-1,063 *$ & & -992.4 \\
\hline & $(639.4)$ & & $(643.4)$ \\
\hline \multirow[t]{2}{*}{ She Retired } & & -644.1 & -283.4 \\
\hline & & $(590.2)$ & $(573.3)$ \\
\hline \multirow[t]{2}{*}{ Number of children still at home } & $925.8 * * *$ & $969.3 * * *$ & $972.8 * * *$ \\
\hline & $(132.6)$ & $(136.0)$ & $(132.5)$ \\
\hline \multirow[t]{2}{*}{ Number of children left home } & $-80.44 *$ & -54.34 & -48.03 \\
\hline & $(48.36)$ & $(47.16)$ & $(47.63)$ \\
\hline \multirow[t]{2}{*}{ He Intermed. Educ. Tech. } & 242.4 & & 69.17 \\
\hline & $(159.7)$ & & $(160.6)$ \\
\hline \multirow[t]{2}{*}{ He Intermed. Educ. general } & 339.7 & & -11.30 \\
\hline & $(265.9)$ & & $(272.0)$ \\
\hline \multirow[t]{2}{*}{ He High School, technical } & 364.5 & & 146.4 \\
\hline & $(270.2)$ & & $(266.3)$ \\
\hline \multirow[t]{2}{*}{ He High School, general } & $1,104 * * *$ & & $541.6^{*}$ \\
\hline & $(310.1)$ & & $(322.5)$ \\
\hline \multirow[t]{2}{*}{ He College short degree } & $755.0 * *$ & & 177.5 \\
\hline & $(309.3)$ & & $(324.4)$ \\
\hline \multirow[t]{2}{*}{ He College and more } & $1,164 * * *$ & & 387.2 \\
\hline & $(289.2)$ & & (373.9) \\
\hline \multirow[t]{2}{*}{ She Intermed. Educ. technical } & & $449.4 * *$ & $394.5^{* *}$ \\
\hline & & $(174.7)$ & $(176.7)$ \\
\hline \multirow[t]{2}{*}{ She Intermed. Educ. general } & & $796.6 * * *$ & $736.8 * * *$ \\
\hline & & $(216.2)$ & $(220.8)$ \\
\hline \multirow[t]{2}{*}{ She High School, technical } & & $931.2 * *$ & $785.9 * *$ \\
\hline & & $(401.1)$ & $(396.2)$ \\
\hline \multirow[t]{2}{*}{ She High School, general } & & $865.3 * * *$ & $575.0 * *$ \\
\hline & & $(242.6)$ & $(278.9)$ \\
\hline \multirow[t]{2}{*}{ She College short degree } & & $1,691 * * *$ & $1,361 * * *$ \\
\hline & & $(284.8)$ & $(320.2)$ \\
\hline \multirow[t]{2}{*}{ She College and more } & & $1,523 * * *$ & $1,110 * * *$ \\
\hline & & $(314.9)$ & $(399.2)$ \\
\hline \multirow[t]{2}{*}{ He French } & $563.8^{*}$ & & 423.1 \\
\hline & $(309.5)$ & & $(360.9)$ \\
\hline \multirow[t]{2}{*}{ She French } & & $531.3^{*}$ & 307.9 \\
\hline & & $(315.1)$ & $(367.1)$ \\
\hline \multirow[t]{2}{*}{ Married } & 20.01 & 108.5 & 152.8 \\
\hline & $(382.3)$ & $(357.5)$ & $(362.0)$ \\
\hline \multirow[t]{2}{*}{ Inner Paris } & $478.5 * *$ & $524.6^{* *}$ & $492.9 * *$ \\
\hline & $(230.7)$ & (229.3) & $(228.6)$ \\
\hline \multirow[t]{2}{*}{ Region of Paris } & 76.09 & 155.7 & 161.5 \\
\hline & $(165.8)$ & $(165.7)$ & $(165.2)$ \\
\hline Observations & 1067 & 1067 & 1067 \\
\hline
\end{tabular}


Table C. The effect of retirement on household clothing consumption: estimation results for the sample of couples in which each partner is either employed or retired.

\begin{tabular}{|c|c|c|c|}
\hline \multirow[b]{2}{*}{ Mean Clothing consumption 55-59 } & (1) & (2) & (3) \\
\hline & 1603 & 1603 & 1603 \\
\hline \multirow[t]{2}{*}{ He Retired } & $-1,004 * *$ & & $-967.6^{* *}$ \\
\hline & $(435.4)$ & & $(470.4)$ \\
\hline \multirow[t]{2}{*}{ She Retired } & & -85.46 & -112.2 \\
\hline & & $(385.9)$ & $(381.9)$ \\
\hline \multirow[t]{2}{*}{ Number of children still at home } & $290.2^{* * *}$ & $360.1 * * *$ & $305.6 * * *$ \\
\hline & $(97.65)$ & $(88.99)$ & $(86.20)$ \\
\hline \multirow[t]{2}{*}{ Number of children left home } & $-60.78 *$ & -24.34 & -44.64 \\
\hline & $(31.01)$ & $(36.30)$ & $(31.95)$ \\
\hline \multirow[t]{2}{*}{ He Intermed. Educ. Tech. } & $234.9 * * *$ & & 127.3 \\
\hline & $(88.98)$ & & (90.18) \\
\hline \multirow[t]{2}{*}{ He Intermed. Educ. general } & $682.8 * * *$ & & $528.0 * * *$ \\
\hline & $(156.5)$ & & $(158.7)$ \\
\hline \multirow[t]{2}{*}{ He High School, technical } & $656.4 * * *$ & & $548.1 * * *$ \\
\hline & $(206.7)$ & & $(208.2)$ \\
\hline \multirow[t]{2}{*}{ He High School, general } & $612.5 * * *$ & & 278.0 \\
\hline & $(214.9)$ & & $(228.2)$ \\
\hline \multirow[t]{2}{*}{ He College short degree } & $740.3 * * *$ & & $483.6 * *$ \\
\hline & $(225.2)$ & & $(226.1)$ \\
\hline \multirow[t]{2}{*}{ He College and more } & $1,224 * * *$ & & $736.9 * *$ \\
\hline & $(292.2)$ & & $(314.4)$ \\
\hline \multirow[t]{2}{*}{ She Intermed. Educ. technical } & & $413.9^{* * *}$ & $317.3 * * *$ \\
\hline & & $(110.7)$ & $(113.2)$ \\
\hline \multirow[t]{2}{*}{ She Intermed. Educ. general } & & $722.0 * * *$ & $444.5 * * *$ \\
\hline & & $(168.6)$ & $(157.5)$ \\
\hline \multirow[t]{2}{*}{ She High School, technical } & & $622.7 * *$ & 439.2 \\
\hline & & $(284.4)$ & $(268.8)$ \\
\hline \multirow[t]{2}{*}{ She High School, general } & & $847.3 * * *$ & $545.8 * * *$ \\
\hline & & $(166.8)$ & $(181.8)$ \\
\hline \multirow[t]{2}{*}{ She College short degree } & & $895.4 * * *$ & $432.5 * *$ \\
\hline & & $(202.7)$ & $(213.0)$ \\
\hline \multirow[t]{2}{*}{ She College and more } & & $1,925^{* * *}$ & $956.2 * *$ \\
\hline & & $(370.2)$ & $(385.2)$ \\
\hline \multirow[t]{2}{*}{ He French } & $368.4 * *$ & & $374.2^{*}$ \\
\hline & $(162.1)$ & & $(219.6)$ \\
\hline \multirow[t]{2}{*}{ She French } & & $330.5^{*}$ & 12.10 \\
\hline & & $(180.3)$ & $(259.4)$ \\
\hline \multirow[t]{2}{*}{ Married } & -201.3 & -11.37 & -153.0 \\
\hline & $(188.3)$ & $(177.5)$ & $(185.0)$ \\
\hline \multirow[t]{2}{*}{ Inner Paris } & $403.6 * * *$ & $362.0 * *$ & $372.7 * *$ \\
\hline & $(152.9)$ & $(154.9)$ & $(146.7)$ \\
\hline \multirow[t]{2}{*}{ Region of Paris } & 17.70 & 159.9 & 58.35 \\
\hline & $(142.0)$ & $(157.8)$ & $(134.5)$ \\
\hline Observations & 1067 & 1067 & 1067 \\
\hline
\end{tabular}




\begin{tabular}{|c|c|c|c|c|}
\hline \multirow{3}{*}{$\mathrm{He}$ is $60=\mathrm{Dm}$} & \multirow{3}{*}{$\begin{array}{c}\text { (1) He retired } \\
0.181 * * \\
(0.085)\end{array}$} & \multirow{3}{*}{ (2) She retired } & \multicolumn{2}{|c|}{ (3) Both retired } \\
\hline & & & $0.182 * *$ & 0.044 \\
\hline & & & $(0.085)$ & $(0.063)$ \\
\hline \multirow[t]{2}{*}{ Dm (His age) } & $-0.073 * *$ & & $-0.075^{* *}$ & -0.0002 \\
\hline & $(0.032)$ & & $(0.032)$ & $(0.026)$ \\
\hline \multirow[t]{2}{*}{ Dm $(\text { His age })^{\wedge} 2$} & $-0.013 * * *$ & & $-0.013 * * *$ & 0.003 \\
\hline & $(0.003)$ & & $(0.003)$ & $(0.002)$ \\
\hline \multirow[t]{2}{*}{ She is $60=\mathrm{Df}$} & & $0.232 * *$ & -0.014 & $0.226 * *$ \\
\hline & & $(0.083)$ & $(0.060)$ & $(0.084)$ \\
\hline \multirow[t]{2}{*}{ Df (Her age) } & & $-0.068 * *$ & 0.028 & $-0.074 * *$ \\
\hline & & $(0.030)$ & $(0.026)$ & $(0.031)$ \\
\hline \multirow[t]{2}{*}{ Df $(\text { Her age })^{\wedge} 2$} & & $-0.011 * * *$ & -0.0001 & $-0.012 * *$ \\
\hline & & $(0.002)$ & $(0.002)$ & $(0.003)$ \\
\hline \multicolumn{5}{|c|}{ b) First Stage Regressions: models including all covariates } \\
\hline & (1) He retired & (2) She retired & (3) $\mathrm{B}$ & tired \\
\hline \multirow[t]{2}{*}{$\mathrm{He}$ is $60=\mathrm{Dm}$} & $0.178^{* *}$ & & $0.168^{* *}$ & 0.053 \\
\hline & $(0.084)$ & & $(0.084)$ & $(0.064)$ \\
\hline \multirow[t]{2}{*}{ She is $60=\mathrm{Df}$} & & $0.226^{* *}$ & -0.003 & $0.230 * *$ \\
\hline & & $(0.084)$ & $(0.059)$ & $(0.083)$ \\
\hline Observations & & 1067 & 1067 & 1067 \\
\hline
\end{tabular}

